\begin{tabular}{l|l|l|l}
$\begin{array}{c}\text { Case Reports in } \\
\text { Demillatology }\end{array}$ & $\begin{array}{l}\text { Case Rep Dermatol 2011;3:28-31 } \\
\text { DOI: } 10.1159 / 000324619\end{array}$ & $\begin{array}{l}\text { Published online: } \\
\text { February 5, 2011 }\end{array}$ & $\begin{array}{l}\text { I 2011 S. Karger AG, Basel } \\
\text { ISSN 1662-6567 } \\
\text { www.karger.com/cde }\end{array}$ \\
\hline
\end{tabular}

\title{
Vitiligo during Treatment of Crohn's Disease with Adalimumab: Adverse Effect or Co-Occurrence?
}

\author{
Celia Posada ${ }^{a}$ Ángeles Flórez ${ }^{\mathrm{a}} \quad$ Ana Batalla ${ }^{\mathrm{a}}$ \\ Juan José Alcázar ${ }^{\mathrm{b}}$ Daniel Carpio ${ }^{\mathrm{c}}$ \\ Services of a Dermatology, ${ }^{b}$ Pathology, and ${ }^{\mathrm{C}}$ Grastroenterology, Complexo \\ Hospitalario de Pontevedra, Pontevedra, Spain
}

\section{Key Words}

Adalimumab · Anti-tumor necrosis factor- $a \cdot$ Cutaneous adverse effects · Vitiligo and Crohn's disease

\begin{abstract}
Adalimumab is a fully human monoclonal anti-tumor necrosis factor-a agent that is approved for the treatment of Crohn's disease. It has a good safety profile, injection site reactions being the most common adverse effect. We report a case of a 54-year-old woman with a 30-year history of Crohn's disease who developed achromic patches on the trunk and upper extremities after initiating treatment with adalimumab. Cutaneous biopsy confirmed diagnosis of vitiligo and laboratory testing ruled out thyroid disease. Concomitant occurrence of vitiligo and inflammatory bowel disease, although rare, has been described. A common autoimmune basis could explain this fact. Moreover, multiple cutaneous adverse effects have been described in the literature secondary to biologic treatments, including vitiligo. In this report, we discuss the possibility of vitiligo as secondary to adalimumab treatment or as an association between both diseases.
\end{abstract}

\section{Introduction}

Tumor necrosis factor- $\alpha$ antagonists (anti-TNF $\alpha$ ) are approved for the treatment of dermatologic, rheumatologic and gastroenterologic conditions. Although these drugs have been shown to have a good safety profile, numerous adverse effects have been described, including cutaneous side effects [1]. 


\begin{tabular}{c|l|l|l}
$\begin{array}{c}\text { Case Reports in } \\
\text { Demmatology }\end{array}$ & $\begin{array}{l}\text { Case Rep Dermatol 2011;3:28-31 } \\
\text { DOI: } 10.1159 / 000324619\end{array}$ & $\begin{array}{l}\text { Published online: } \\
\text { February 5, 2011 }\end{array}$ & $\begin{array}{l}\text { O 2011 S. Karger AG, Basel } \\
\text { ISSN 1662-6567 } \\
\text { www.karger.com/cde }\end{array}$ \\
\hline
\end{tabular}

\section{Case Report}

We report a case of a 54-year-old woman with a 30-year history of Crohn's disease with perianal involvement who was unresponsive to multiple antibacterial drugs. Different immunosuppressive agents (6-mercaptopurin, azathioprine and methotrexate) were also attempted, but they had to be stopped due to adverse effects. Treatment with adalimumab was then initiated with standard doses (initial dose: $160 \mathrm{mg}$ in week $0,80 \mathrm{mg}$ in week 2 , and $40 \mathrm{mg}$ every 2 weeks thereafter) resulting in disease control. Eight months after initiation of the therapy, the patient developed different sized achromic patches localized on the ventral aspect of her upper extremities and trunk (fig. 1). Cutaneous biopsy showed no melanocytes in the basal layer of the epidermis and no other changes; thus, the diagnosis of vitiligo was made (fig. 1). Laboratory tests did not find any autoimmune disorders, such as thyroid dysfunction, which are sometimes associated with the diagnosis of vitiligo. Adalimumab was not stopped.

\section{Discussion}

Adalimumab is a fully human monoclonal anti-TNF $\alpha$ that is approved for the treatment of Crohn's disease. Overall, adalimumab is well tolerated. The most common side effect is injection site reaction. Other cutaneous adverse effects have been described secondary to adalimumab treatment and other anti-TNFa drugs, including immunemediated skin conditions $[1,2]$. The most reported events are skin infections, toxicodermias, eczema, pruritus, psoriasis vulgaris and psoriasis-like lesions, leukocytoclastic vasculitis, lupus-like syndrome and cutaneous lupus. To the best of our knowledge, only 4 case reports on vitiligo have been described following biologic treatments [2-4]. Three patients developed vitiligo secondary to infliximab treatment $[2$, 4]. The mechanism of development has been supposed to be the same as in case of the lupus-like syndrome [4]. Smith et al. [3] reported 1 patient who developed vitiligo after resolution of psoriatic plaques during treatment with adalimumab. However, the authors considered the onset of vitiligo to be more related to the Koebner phenomenon rather than being a result of biologic treatment.

In contrast, the use of anti-TNFa agents has been proposed as a possible therapy for vitiligo, as TNFa has shown to play an important role in this disease [5]. Overexpression of TNF $\alpha$ has been found in lesional skin compared to healthy skin. Moreover, case reports on vitiligo successfully treated with infliximab have been described [6].

Vitiligo is widely considered to have an autoimmune basis. Accordingly, the increased associated occurrence of other autoimmune disorders, mainly thyroid disease, supports this theory [7]. Concomitant occurrence with inflammatory bowel disease has been rarely reported [8]. This fact is usually explained to be due to immunologic mechanisms, but whether the association is significant or merely due to chance is an open question.

In our case, doubt exists about whether vitiligo is secondary to the treatment with adalimumab or, on the contrary, whether it develops as an association between 2 autoimmune disorders. The long evolution time of the bowel disease, the abrupt onset, the rapid generalization of cutaneous lesions, and the temporal relationship with initiation of the biologic treatment support the first possibility. Thus, our case seems to be the first reported case of vitiligo secondary to the treatment with adalimumab, if we agree that the case described by Smith et al. [3] was not related to adalimumab.

In conclusion, cutaneous adverse effects of anti-TNFa agents are frequent. Therefore, dermatologists should be familiarized with them, both for a better management of these 


\begin{tabular}{c|l|l|l}
$\begin{array}{c}\text { Case Reports in } \\
\text { Demmatology }\end{array}$ & $\begin{array}{l}\text { Case Rep Dermatol 2011;3:28-31 } \\
\text { DOI: } 10.1159 / 000324619\end{array}$ & $\begin{array}{l}\text { Published online: } \\
\text { February 5, 2011 }\end{array}$ & $\begin{array}{l}\text { O 2011 S. Karger AG, Basel } \\
\text { ISSN 1662-6567 } \\
\text { www.karger.com/cde }\end{array}$ \\
\hline
\end{tabular}

drugs in our field and for recognizing those effects in patients treated with the same agents in other specialties. This is probably the first reported case of vitiligo secondary to the treatment with adalimumab.

\section{Disclosure Statement}

The authors have no conflicts of interest to declare.
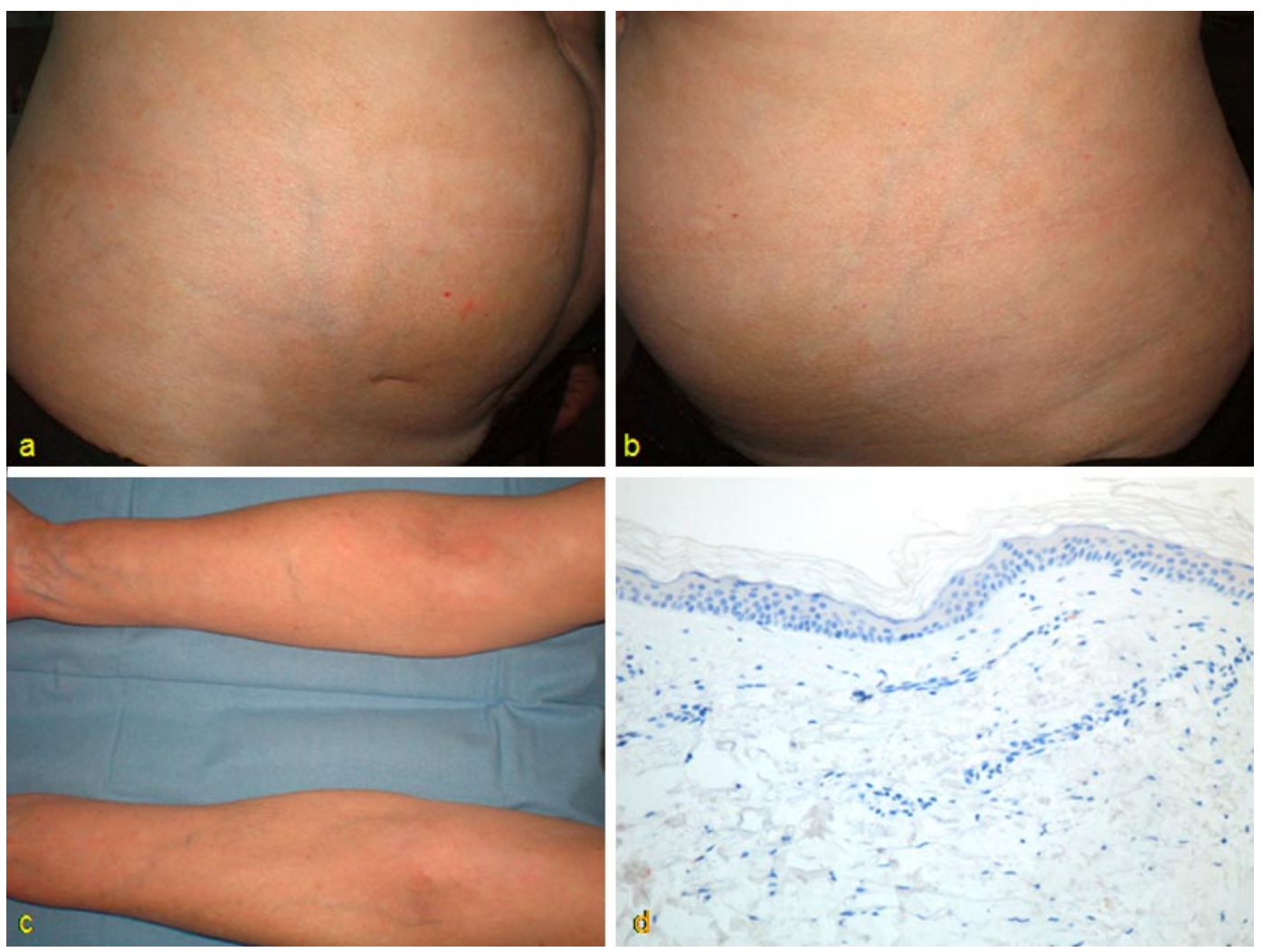

Fig. 1. Achromic patches of different sizes and poorly-defined limits, localized on the trunk and ventral aspect of the patient's upper extremities $(\mathbf{a}-\mathbf{c})$; absence of melanocytes in the basal layer of epidermis [IHQ; HMB-45 ×200] (d). 


\section{References}

1 Flendrie M, Vissers WH, Creemers MC, de Jong EM, van de Kerkhof PC, van Riel PL: Dermatological conditions during TNF-alpha-blocking therapy in patients with rheumatoid arthritis: a prospective study. Arthritis Res Ther 2005;7:R666-R676.

-2 Exarchou SA, Voulgari PV, Markatseli TE, Zioga A, Drosos AA: Immune-mediated skin lesions in patients treated with anti-tumour necrosis factor alpha inhibitors. Scand J Rheumatol 2009;38:328-331.

-3 Smith DI, Heffernan MP: Vitiligo after the resolution of psoriatic plaques during treatment with adalimumab. J Am Acad Dermatol 2008;58(2 suppl):S50-S52.

-4 Ramírez-Hernández M, Marras C, Martínez-Escribano JA: Infliximab-induced vitiligo. Dermatology 2005;210:79-80.

5 Lv Y, Li Q, Wang L, Gao T: Use of anti-tumor necrosis factor agents: a possible therapy for vitiligo. Med Hypotheses 2009;72:546-547.

-6 Simón JA, Burgos-Vargas R: Vitiligo improvement in a patient with ankylosing spondylitis treated with infliximab. Dermatology 2008;216:234-235.

7 Alkhateeb A, Fain PR, Thody A, Bennett DC, Spritz RA: Epidemiology of vitiligo and associated autoimmune diseases in Caucasian probands and their families. Pigment Cell Res 2003;16:208-214.

-8 Pashankar D, Prendiville J, Israel DM: Vitiligo and Crohn's disease in children. J Pediatr Gastroenterol Nutr 1999;28:227-229. 